\title{
POLA KERUANGAN KRIMINALITAS PERKOTAAN
}

\author{
Oleh: Dilahur
}

\begin{abstract}
$\overline{\text { ABSTRACT }}$
The problem of criminality tends to increase qualitative as well as quantitative parallel to so much the complexity of human living. The kind of criminality is various likewise the motivation factors. The sort classification of criminality and its theory are various looking at its from the science and experts. Geography examines the criminality at the view point of spatial, ecological and regional. At the spatial side, it will be found the proliferation of various criminality either the place of origin or the place of where it operate and spatial association with all the factors of social, economy, culture and environment. Not all of the criminality point-out the clear spatial pattern. Geography is able to contribute the solution for the criminality affair in the urban with the spatial, ecological, and regional approach.
\end{abstract}

\section{$\overline{\text { ABSTRAK }}$}

Masalah kejahatan cenderung meningkat secara kualitatif maupun kuantitatif bersama dengan semakin kompleknya kehidupan manusia. Jenis kejahatan bervariasi demikian pula dengan faktor-faktor penyebabnya. Penggolongan jenis kejahatan dan teorinya bervariasi dari berbagai ahli dan disiplin ilmu. Geografi mengkaji kejahatan dari segi keruangan, lingkungan dan kewilayahan. Dari segi keruangan akan diperoleh persebaran berbagai jenis kejahatan baik asal pelaku maupun tempat peristiwa kejahatan terjadi serta asosiasi keruangannya dengan faktor-faktor sosial, ekonomi, budaya dan lingkungan. Tidak semua jenis kejahatan mempunyai pola keruangan yang jelas. Geografi dapat memberi sumbangan terhadap pemecahan masalah kejahatan di perkotaan dengan pendekatan keruangan, lingkungan dan wilayah tersebut.

\section{PENDAHULUAN}

Menurut pendapat umum, dengan bertambahnya kemakmuran, biasanya kejahatan otomatis akan berkurang. Tetapi kebalikannya di Indonesia, walaupun kemakmuran rakyat telah bertambah, namun frekuensi dan situasi kejahatan lebih buruk dari sebelumnya (Nasution, 1982). Selanjutnya pada tulisan tersebut dikatakan masa sekarang sesungguhnya 
ditandai oleh suatu peningkatan kejahatan, kekerasan, teorisme, dan lain-lain secara luar biasa. Ada kalanya timbul suatu perasaan yang tidak menentu dalam kota-kota besar, yang telah menyebabkan kekurangan percayaan terhadap pemberantasan kejahatan dengan cara mekanisme peradilan kriminal. Jika hal ini dibiasakan, lama kelamaan orang akan lebih meng gantungkan diri pada usaha perlindungan diri secara preventif, dari pada aparat penegak hukum yang resmi.

Menurut Dirdjosisworo, (1984) berbagai permasalahan yang timbul dalam era pembangunan yang laju pesat ini diantaranya adalah :

a. Meningkatnya kriminalitas dalam berbagai bentuk dan polanya, baik secara kuantitas maupun kualitas telah dirasakan dampak negatif yang berupa hambatan terhadap pelaksanaan pembangunan. Sebagai akibat peningkatan kejahatan yang sukar dikendalikan dan ditanggulangi, pemerintah akan dihadapkan pada kerugian-kerugian material berupa harta benda bahkan nyawa korban kriminalitas. Disamping itu tidak boleh dilupakan masalah biaya yang diperlukan untuk menanggulangi kejahatan. Selain kerugian material akibat mengganasnya kejahatan akan menimbulkan pula kerugian non-material, yaitu akan terasa berkurangnya kewibawaan pemerintah. b. Sebagai salah satu pengaruh luasnya pembangunan adalah suatu kondisi yang menimbulkan berbagai faktor yang berkorelasi dengan lemahnya mekanisme pengawasan terhadap mekanisme pembangunan. Hal disebabkan karena perubahan sosial yang membentuk berbagai keadaan yang dapat merupakan faktor-faktor kriminologik, yang terarah akan menimbulkan kesulitan di dalam mengidentifikasi berbagai bentuk kriminologi, yang pada gilirannya akan berpengaruh mendorong laju kriminalitas. Disamping faktor kriminolgik ini maka efek samping yang cukup menonjol adalah berkembangnya sub-budaya kelompok yang sadar atau tidak malahan mendukung pandangan yang cenderung acuh tak acuh terhadap perilaku yang melanggar undangundang daripada untuk mendukung penegak undang-undang.

c. Tidak dapat disangkal bahwa faktor struktur sosial budaya dipengaruhi oleh proses pergeseran sosial. Agaknya tidak dapat disangkal pula bahwa faktor struktur sosial budaya sering kali menimbulkan dampak negatif, misalnya pelanggaran terhadap norma-norma hukum yang berlaku. Sebaliknya faktor sosial budaya struktural apabila dimanfaatkan dan didayagunakan, merupakan pula sarana yang ampuh dalam upaya penanggulangan 
kriminalita, termasuk dalam bentuk perilaku korupsi.

Kriminalitas dengan demikian merupakan akibat dari berbagai sebabsebab yang saling berkaitan. William J. Chamblis dalam Kusumah (1982), mengutarakan bahwa kejahatan adalah suatu gejala politik, ekonomi dan sosial yang benar-benar kompleks yang harus secara sistematik dipelajari dari banyak segi. Pada kenyataan di muka bumi selalu terjadi gejala differensiasi baik kondisi, potensi dan permasalahan antar wilayah. demikian pula dengan defferensiasi tingkat kriminalitas antar wilayah, dengan kata lain kriminalitas merupakan gejala keruangan atau geografis pula. Masalahnya studi kriminalitas dari sudut pandang geografi masih sedikit sekali dilakukan di Indonesia, sehingga sumbangan disiplin ini untuk memecahkan permasalahan tersebut masih belum diketahui. Persoalan kriminalitas tidak mudah dikaji dari segi geografi. Hal ini disebabkan oleh kompleksitas permasalahan tersebut, sehingga harus dicari terlebih dahulu segi-segi kriminalitas yang memiliki gejala kekurangan baik menyangkut latar belakang pelaku maupun tempat peristiwa kejahatan terjadi. Pemecahan masalah kriminaltas memerlukan penilaian terhadap bagian wilayah kota yang menjadi sumber pelaku kejahatan dan keruangan dari aktivitasnya, dengan demikian dapat direncanakan penanganan yang lebih tepat sesuai dengan faktor-faktor penyebabnya. Dalam hal ini terdapat gejala yang nampak di daerah perkotaan yaitu ;

1. Pola keruangan tempat asal pelaku kriminal dan tempat melakukan aktivitas kriminal bervariasi diantara berbagai jenis kriminalitas.

2. Daerah asal pelaku kriminal tidak merata di seluruh wilayah perkotaan tetapi pada bagian-bagian tertentu yang perlu diteliti karakteristik sosial, ekonomi dan lingkungannya.

\section{KRIMINALITAS, JENIS DAN FAKTOR PENYEBABNYA}

Kejahatan adalah suatu nama atau cap yang diberikan orang untuk menilai perbuatan-perbuatan tertentu, sebagai perbuatan jahat. Dengan demikian maka sipelaku disebut penjahat. Oleh karena pengertian tersebut bersumber dari alam nilai maka ia memiliki yang sangat relatif, yaitu sangat bergantung pada manusia yang memberikan penilaian itu (Bawengan, 1977). Berdasarkan definisi legalistik atau menurut undang-undang/hukum, kejahatan (crime) adalah suatu perbuatan manusia yang melanggar hukum kriminal (Barlow, 1984). Berdasarkan azas legalistik pula dapat dibedakan antara kejahatan dan pelanggaran. Menurut kata-kata utrecht dalam bawengan (1977), kejahatan adalah perbuatan karena sifatnya bertentangan dengan ketertiban hukum sedangkan pelanggaran adalah 
perbuatan yang oleh undang-undang dicap suatu perbuatan yang bertentangan dengan ketertiban hukum.

Untuk memudahkan mempelajari Bonger dalam Dirdjosisworo (1984) menggolngkan berbagai kejahatan kedalam empat golongan yakni :

1. Kejahatan ekonomi

2. Kejahatan seksual

3. Kejahatan struktural

4. Kejahatan politik

Sedangkan Cavar dalam Dirdjosis woro (1984), Bawengan (1977) membagi menjadi 9 type penjahat, yaitu :

1. The Causial Offender

2. The Occasional Criminal (keduanya adalah orang-orang yang melakukan pelanggaran ringan)

3. The Episodik Criminal (orang orang yang melakukan kejahatan didorong oleh luapan emosi yang tak terkendalikan).

4. The White Collar Criminal (kejahatan yang dilakukan oleh orang-orang yang kuat dalam kepangkatan, politik dan ekonomi).

5. The Habitual Criminal (penjahat yang suka mengulang perbuatan nya, contoh adalah residivis).

6. The Profesional Criminal (yang melakukan kejahatan sebagai mata pencaharian).

7. The Organized Criminal (penjahat yany tergabung dalam organisasi kejahatan atau kejahatan yang terorganisir).

8. The Mentally Abnormal Criminal (orang yang melakukan kejahatan didorong kejiwaan yang tak normal (psikopatis-psikotos).

9. The Nonmalicions Criminal (orang-orang yang melakukan pelanggaran hukum, namun sipelaku tidak menganggap dirinya berbuat kejahatan, karena ia berpegang pada pendirian kepercayaan tertentu.

Tentang sebab-sebab terjadinya kejahatan, sudah banyak didefinisikan orang. Identifikasi tersebut mungkin dilakukan secara monodisipliner atau Interdisipliner. Masing-masing mempunyai kelebihan dan kekurangan, sehingga tidak ada kesepakatan yang bulat. Yang ada hanya kesepakatan bahwa kejahatan disebabkan oleh berbagai faktor yang saling berkaitan, dan harus ditelaah secara menyeluruh bila hendak dicegah atau diatasi (Soekamto, 1982). Menurut Soekamto (1982), ada kecenderungan untuk menyatakan bahwa kejahatan terjadi karena ketidak serasian pada individu, khususnya mengenai hubungan timbal balik antara faktor-faktor ekspresif dengan kekuatan-kekuatan normatif. Kekuatan-kekuatan ekspresif mencakup faktor-faktor psikologis dan biologis yaitu meliputi :

1. Faktor-faktor biopsikogenik terdiri dari; mesomorfik fisik, yakni keadaan fisik yang dikaitkan dengan sifat atau temperamen tertentu yang menyebabkan perilaku jahat; gangguan psikologis, seperti gangguan syaraf, ego yang defektif, 
dan seterusnya; ekses dan kebutuhan, misalnya, alkoholisme, kecanduan narkotik, dan lain-lain.

2 Faktor-faktor sosioganik yang meliputi : asosiasi, deferensial, misalnya, menjadi anggota gang, asosiasi dengan pola perilaku kriminal, dan seterusnya; frustasi karena perbedaan perlakuan atau kepahitan dimasa lampau (seperti misalnya yang terdapat pada bekas narapidana); tekanan-tekanan karena rasa takut, adanya ancamanancaman, kemiskinan dan lain sebaginya.

Sedangkan kekuatan-kekuatan normatif yang mencakup faktor keluarga atau kehidupan kekeluargaan, agama dan faktor sosio-kultural, dapat dijabarkan sebagai berikut :

1. Faktor lingkungan yang fundamental, yang mencakup taraf kepatuhan agama yang relatif rendah, oleh karena tidak berhasil menjiwai ajaran dan norma norma agama; gangguan dalam kehidupan keluarga, umpamanya : tidak ada bimbingan orang tua, pecahnya keluarga, dan sebagainya; di organisasi sosial, seperti misalnya, pudarnya nilai dan norma-norma yang mengakibatkan warga negara kehilangan pedoman untuk berperilaku secara pantas.

2. Faktor-faktor pendukung dalam lingkungan, yang terdiri dari; kesempatan atau peluang; moralitas sosial yang relatif rendah; konflik kebudayaan atau konflik antara bagian-bagian dari suatu kebudayaan.

Menurut Natonal Advisory Commision On Criminal yustice standart and Goal United State (inciardi and Siegal, 1977), setiap studi kriminal yang serius dicatat asosiasi antara fluktuasi-fluktuasi dalam angka/tingkat kejahatan dan perubahan-perubahan kependuduk an, nilai-nilai sosial, dan kondisi ekonomi.

Diantara kondisi-kondisi masyarakat yang sangat sering berhubungan dengan masalah kejahatan adalah sebagai berikut :

- Proporsi kelompok muda dalam penduduk

- Pertumbuhan penduduk daerah Metropolitan

- Mobilitas penduduk

- Stabilitas keluarga

- Distribusi pendapatan

Sheley (1987) menyatakan bahwa sebagian besar penelitian psikologi terhadap aktivitas penjahat dipusatkan pada kekacauan kepribadian. Pendekatan sosiologis untuk menjelaskan penjahat dilain pihak, cenderung memandang perilaku penjahat agak lebih normal, dianggap tanggap terhadap kejadian-kejadian dan situasi-situasi sosial dan kultural. Usaha menjelaskan secara teoritis ada 3 bentuk:

Teori ketegangan, Struktural, teori penyebaran kultural dan teori kontrol. Teori ketegangan struktural memusat- 
kan atas kelemahan- kelemahan dalam berbagai lembaga sosial sebagai sumber dari permasalahan atau ketegangan untuk anggota masyarakat. Kejadian dilihat sebagai tanggapan terhadap ketegangan tersebut. Secara tradisional, kaum strukturalis memandang tiga lembaga sebagai sumber perilaku penjahat : Keluarga, agama dan Sistem ekonomi.

Tema sentral dari teori penyegaran budaya adalah bahwa masyarakat yang agak besar secara kultural dan ekonomi cukup heterogen untuk menghasilkan sejumlah kelompok dimana nilai-nilai dan kepercayaanya (dan oleh karena itu perilakunya berbeda). Dengan demikian kriminalitas adalah proses yang secara normal memainkan peran (hal itu adalah sesuai dengan suatu tata nilai yang dipelajari) tetapi, secara tidak menguntungkan, dalam suatu cara/ sikap itu bertentangan dengan nilai yang dipelajari oleh suatu kelompok yang lebih kuat.

Teori kontrol memusatkan penjelasannya tidak pada motivasi untuk menyimpang tetapi atas gangguangangguan terhadap tindakan menyimpang.

Herberet (1982) secara diagramatik menunjukkan sifat- sifat obyektif yang umum dari pelaku pelanggaran daerah perkotaan sebagai berikut :

\begin{tabular}{|c|c|c|}
\hline Kategori & Indikator & Sub- \\
\hline & & $\begin{array}{l}\text { kelompok } \\
\text { beresiko }\end{array}$ \\
\hline & hur ............... & Muda \\
\hline
\end{tabular}

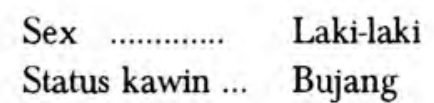

Demografi Status

fi Status

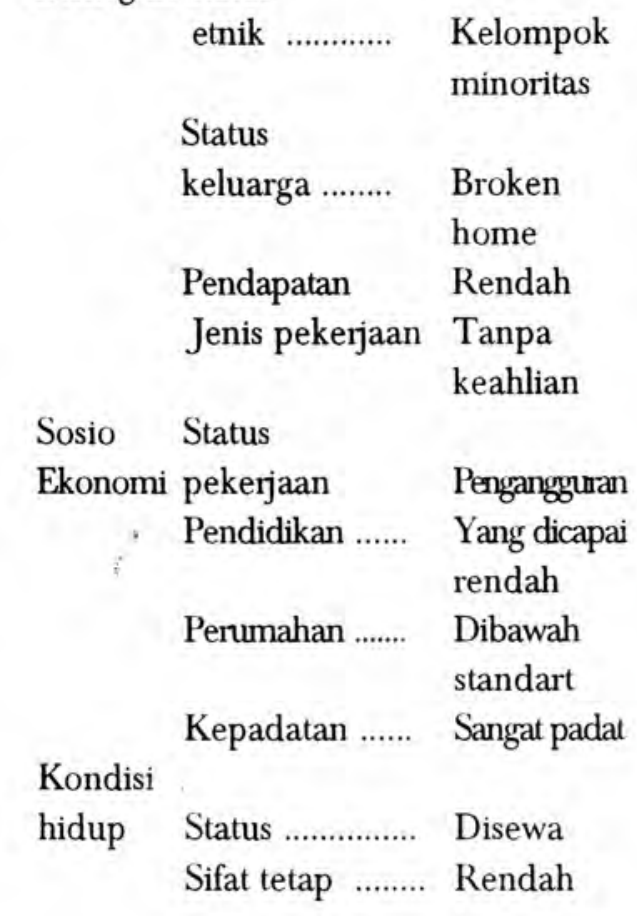

Dari berbagi teori dan pendapat di atas dapat dikatakan bahwa ada berbagai sebab-sebab dari timbulnya penjahat dan kejahatan, serta karakteristiknya. Karakteristik kejahatan dapat dilihat pada pelaku kejahatan maupun daerah asal dari penjahat. Disamping itu dapat dipelajari pola hubungan keruangan antara daerah asal penjahat dengan daerah operasinya. Walaupun demikian tidak semua jenis kejahatan dapat/mudah dikaji dari segi keruangannya. Hal ini disebabkan tidak semua jenis kejahatan memiliki keteraturan polanya secara keruangan seperti The Episodic Crimi- 
nal, The Mentally Abnormal Criminal atau The Normalicions. Dalam hal sebab-sebab atau latar belakang pelaku kejahatan juga tidak seluruhnya mempunyai pola keruangan tertentu seperti status keluarga Broken home dan sebagainya.

\section{SEGI-SEGI KERUANGAN DAN MODEL TEORITIS KRI- MINALITAS}

Welfare geography adalah suatu aspek dari human geography yang berkembang pada dasa warsa 1970 an, dan menyimpang dari revolusi kuantitatif, karena ingin memperhatikan kualitas hidup, keadilan wilayah dan kesejahteraan. Masalah- masalah yang ditangani adalah seperti kemiskinan, kelaparan, kejahatan, kurangnya perumahan dan pelayanan sosial yang pincang (Daldjoeni, 1989).

Perhatian terhadap masalah kriminalitas ini telah memberikan alternatif kajian dari sudut pandang yang berbeda. Kajian geografi terutama dari sudut pandang keruangan memperhatikan gejala melalui keberadaannya dalam ruang yang meliputi letak distribusi, asosiasi dengan gejala lainnya, jarak interaksi kekurangan, perubahan ruangan dan gejala kekurangan lainnya.

Kajian geografi terhadap masalah kriminalitas dapat menggunakan skala analisa yang bervarian yaitu ;

Skala Unit observasi Studi dari segi

Regional Negara,

$\begin{array}{ll}\text { Kabupaten } & \text { Variasi } \\ \text { Wilayah } & \text { regional } \\ \text { kepolisian } & \end{array}$

Kota Distrik kota, bidang

Ekologi

Kota,

Daerah

Patroli blok

Individual Unit tempat

$\begin{array}{ll}\begin{array}{l}\text { tinggal } \\ \text { Ruang. }\end{array} & \text { Kenampak } \\ \text { jalan. } & \text { an situasi }\end{array}$

(Herbert, 1982:54)

Pada skala kota analisis keruangan dikaitkan dengan kondisi lingkungan atau pada variasi keruangan dari kondisi lingkungan seperti pemukiman, tempat-tempat kegiatan ekonomi dan sosial, jaringan transportasi dengan berbagai variasinya.

Barlow (1984) menyatakan bahwa pakar geografi mengajari kita banyak tentang dimana peristiwa-peristiwa kejahatan terjadi dan tentang gerakan/perpindahan dari pelanggarpelanggar kejahatan ke dan dari tempat/situasi kejahatan, bergandengan dengan studi-studi dari pemilihan sasaran, pekerjaan ini menawarkan pengertian/wawasan baru terhadap mata rantai antara sasaran penjahat, aktivitas rutin, dan pengambilan keputusan penjahat. Sebagian besar pekerjaan penting ini difokuskan pada peristiwa-peristiwa kejahatan yang terjadi didaerah perkotaan. Aktivitas rutin dapat dilihat dari suatu pandangan keruangan. Keadaan yang 
biasa, secara individual tumbuh akrab dengan bagian-bagian kota tertentu jalur ke tempat kerja, tetangga dekat, pusat perbelanjaan lokal, tempat hiburan, daerah daerah dimana temanteman dan tempat tinggal sementara dan seterusnya.

Distribusi angka-angka pelanggaran juga dikaitkan dengan karakteristik sosial dari daerah-daerah dalam kota. Dalam berbagai sumber kita tahu kesimpulan bahwa angka pelanggaran dari daerah tersebut berkaitan dengan; 1. Kondisi sosial ekonomi, 2. Perumahan dan karakteristik keluarga, 3 . Derajat pengelompokan etnik dan ras (Quiney, 1979).

Davidson (1980) dalam penelitian pencurian kecil di kota Christchurch, New Zealand menemukan bahwa daerah sasaran atau daerah asal pencuri adalah daerah pemukiman kelas menengah dan bawah, pada bagian tengah kota. Ciri-ciri pencuri kebanyakan usia muda, pengangguran atau kurang aktif ekonominya, Maori dan penduduk asli kepulauan Pasifik lebih banyak. Sedangkan hubungan antara tempat tinggal pencuri dengan sasaran berjarak antara tiga atau empat kilometer.

Seperti dikemukakan di muka bahwa tidak semua jenis kejahatan menunjukan gejala keruangan yang jelas baik asal tempat tinggal maupun tempat melakukan kejahatan. Namun demikian pada jenis kejahatan lainnya menunjukan indikasi tempat asal pelaku yang relatif dapat diidentifikasi dan pada jenis kejahatan lainnya menunjukan gejala yang jelas baik tempat asal pelaku kejahatan maupun daerah operasinya seperti pada naditual Criminal, Oleh karena itu hanya pada beberapa jenis kejahatan dapat dibuata model teoritis yang umum.

Pada pembahasan dimuka dapat diidentifikasi faktor-faktor demografi, sosial ekonomi dan lingkungan yang mempengaruhi timbulnya daerahdaerah yang menghasilkan pelaku beberapa jenis kejahatan. Pada tulisan ini model yang dibuat hanya menyangkut kejahatan pencurian (pencuri di rumah, copet dan sebagainya). Model ini menyangkut hubungan antara tempat asal dan tempat operasi kejahatan dalam bentuk diagram sebagai berikut :

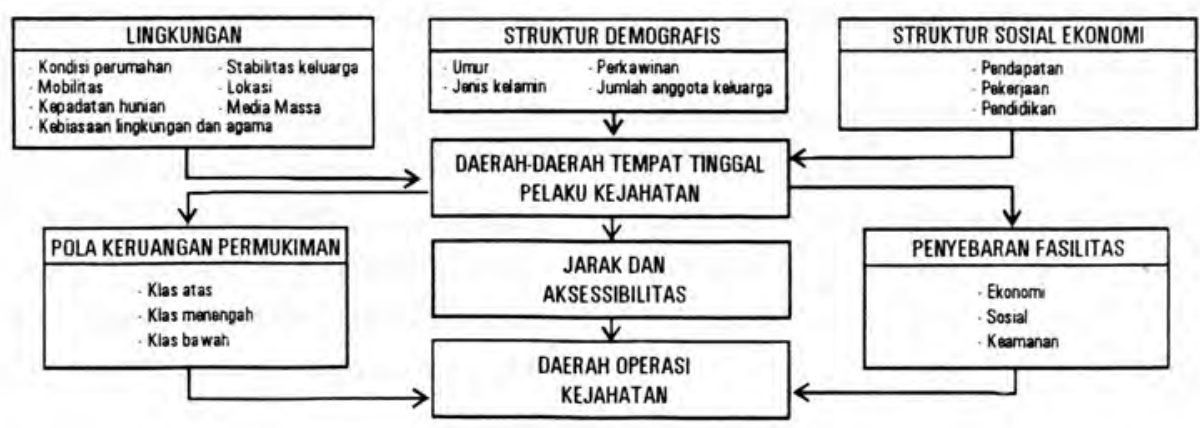


Berbagai kemungkinan timbulnya daerah-daerah/kantong-kantong tempat tinggal pelaku kejahatan diakibatkan oleh struktur sosial ekonomi yang timpang dalam masyarakat dan tercerminkan pada terbentuknya bagian-bagian kota yang berbeda antara pemukiman elit, menengah dan klas bawah. Hal ini merupakan hasil proses marjinalisasi masyarakat dalam persaingan di bidang ekonomi dan sosial. Suksesi keruangan terus berlangsung sehingga akhirnya akan menghasilkan segregasi ruang kota yang nyata. Di beberapa kota proses ini nampaknya juga terjadi namun kantong-kantong kejahatan tidak semuanya akibat dari marjinalisasi ini. Ada sebagian diakibatkan masuknya daerah pedesaan di sekitar kota kedalam lingkungan perkotaan karena perluasan/wilayah kota, tetapi penduduknya secara ekonomi belum terintegrasi kedalam sistem ekonomi perkotaan. Hal ini tercermin pada ciri-ciri pendapatan yang relatif rendah, pendidikan rendah dan pekerjaan sektor informal.

Dari segi demografis kantongkantong kejahatan dicerminkan oleh struktur penduduk muda dengan beban tanggungan lebih besar dibanding daerah lain. Sedangkan dari segi lingkungan dicerminkan oleh kondisi permukiman yang kurang sehat, rumah relatif kecil, rapat/padat dengan kepadatan hunian yang relatif tinggi. Kebiasaan-kebiasaan berjudi, minum-minuman keras, konflik keluarga, perceraian, dan kurang/tak acuh terhadap agama, lebih mewarnai kehidupan bagian yang relatif besar dari penduduknya.

Selanjutnya operasi kejahatan dilakukan bervariași dari berbagai jenis kejahatan. Pada kejahatan pencopetan misalnya, tempat-tempat keramaian atau fasilitas ekonomi (pasar, pertokoan, Transportasi). Sedangkan pencurian kecil sering terjadi pada permukiman kelas menengah dan bawah karena sistem keamanannya yang relatif kurang.

\section{PENUTUP}

Penelitian keruangan terhadap kriminalitas di Indonesia masih sangat sedikit sekali. Geografi kriminal mungkin dapat dikembangkan untuk ikut mengantisipasi perkembangan kriminalitas. Nampaknya proses marjinalisasi dan integrasi yang tidak sempurna dari daerah pedesaan kelingkungan perkotaan perlu memperoleh perhatian untuk memperkecil berkembangnya kejahatan. 


\section{$\overline{\text { DAFTAR PUSTAKA }}$}

Barlow, Hugh D., 1984, Intraduction to Criminologi, Boston Little, Brown and Company.

Bawengan, Gerson W. ,1970, Pengantar Psikologi Kriminal, Jakarta, Pradnya paramitra.

Davidson, R.N, 1980, Patterns of residential Burglary in Christchurch, New Zealand Geographer, 36 February.

Dirdjosisworo, Soedjono, 1984, Ruang Lingkup Kriminologi, Bandung, Remaja Karya CV.

Herbert, David, 1982, The Geography of Urban Crime, London, Longman.

Inciardi, James A.and Siegal, Harvey A., 1977, Crime Emerging Issues, New York, Praeger Publishers.

Kusumah, Mulyana W., 1982, Realita Sosial Kejahatan, Prisma, Jakarta, LP3ES, 5 Mei.

Nasution, A. Karim, 1982, Kriminalitas dan Pembangunan, Pencegahan dan Pengendalian, Prisma, Jakarta, LP3ES, 5 Mei.

Quinney, Richard, 1979, Criminologi, Boston, Lettle, Brown and Company.

Sheley, Joseph F., 1987, Exploring Crime, Reading in Criminology and Criminal Justice, Belmont, Wadsworth Publishing Company.

Singarimbun, Masri dan Effendi, Sofian, 1981, Metode Penelitian Survei, Yogyakarta, PPSK, UGM.

Soekanto, Soerjono, 1982, Kejahatan dan sistem Peradilan Pidana, Prisma, Jakarta, LP3ES, 5 Mei. 